\title{
What are the Predictive Factors of the Cure and Complication Rates for Midurethral Slings in the Treatment of Stress Urinary Incontinence in Women: A Multicenter and Multivariate Analysis Study
}

\author{
Kadınlarda Stres Tip İdrar Kaçırma Tedavisinde Midüretral Slinglerin Başarı ve Komplikasyon \\ Oranlarını Etkileyen Faktörler Nelerdir: Çok Merkezli ve Multivaryan Analiz Çalışması
} \author{
Lokman İrkilata ${ }^{5}$, Illker Şen ${ }^{5}$, Tufan Tarcan ${ }^{2}$, Bülent Çetinel ${ }^{1}$ \\ 'İstanbul University Cerrahpaşa Faculty of Medicine, Department of Urology, Istanbul, Turkiye \\ ${ }^{2}$ Marmara University Faculty of Medicine, Department of Urology, Istanbul, Turkiye \\ ${ }^{3}$ Ege University Faculty of Medicine, Department of Urology, Izmir, Turkiye \\ ${ }^{4}$ Kocaeli University Faculty of Medicine, Department of Urology, Kocaeli, Turkiye \\ ${ }^{5}$ Gazi University Faculty of Medicine, Department of Urology, Ankara, Turkiye
}

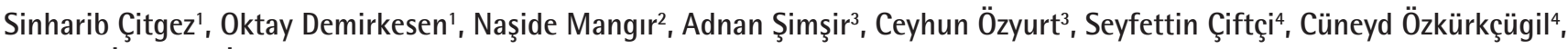

What's known on the subject? and What does the study add?

To our knowledge, this was the biggest multicenter study about midurethral slings in our country. We hope the results will be a guide for the surgeons.

\begin{abstract}
Objective: Predictive factors that could affect the cure and complication rates of midurethral slings (MUS) in the treatment of stress urinary incontinence (SUI) were investigated.

Materials and Methods: A total of 594 women (outside-in transobturator in 285, inside-out transobturator in 91, and retropubic in 218) with SUI and who had undergone MUS were evaluated. The median age was 53.9 (27-82) years. Univariate analyses were done using chi-square test, Student's t-test and the Mann-Whitney U test. Multivariate analyses were done using logistic regression analysis to determine predictive factors affecting cure and complication rates.

Results: The mean follow-up time was 48 months. The subjective cure rate was $84 \%$ and complication rate was $11.2 \%$. On univariate and multivariate analyses, the cure rate was found to be increased in younger patients [odds ratio (OR): 0.97, 95\% confidence interval (CI): $0.95-0.99, p=0.038$ ] and in patients with pure SUI (OR: $2.17,95 \% \mathrm{Cl}: 1.31-3.60, \mathrm{p}=0.002)$. The type of surgery was the only statistically significant parameter affecting the complication rate, which was significantly higher in retropubic MUS procedure (OR: 6.28, 95\% Cl: $3.51-11.22, p<0.001$ ).

Conclusion: MUS is an effective and safe surgical procedure in the treatment of SUI. In this study, age and type of incontinence were the only significant predictive factors affecting the cure rate. Our study suggests that retropubic approach could be considered a risk factor for complication after MUS.
\end{abstract}

Keywords: Stress urinary incontinence, midurethral sling, transobturator, retropubic, complication

Öz

Amaç: Kadınlarda stres tip idrar kaçırma (STIK) tedavisinde midüretral sling (MUS) uygulanmasının sonuç ve komplikasyon oranlarını etkileyen prediktif faktörleri araştırdık.

Gereç ve Yöntem: Ürodinamik STiK tespit edilip MUS uygulanan 594 kadın hasta (285 transobturator dıştan içe, 91 transobturator içten dışa, 218 retropubik) araştırıldı. Ortalama yaş 53,9 (27-82) idi. Univaryan analizde ki-kare, Student-t ve Mann-Whitney U testleri kullanıldı. Multivaryan

Correspondence: Sinharib Çitgez MD, İstanbul University Cerrahpaşa Faculty of Medicine, Department of Urology, İstanbul, Turkiye Phone: +90 5323122377 E-mail: drsinharib@yahoo.com ORCID-ID: orcid.org/0000-0002-3897-2951

Received: $12.01 .2017 \quad$ Accepted: 02.05.2017

Presented in: $3^{\text {rd }}$ National Congress of Functional Urology and Female Urology on 3-6 0ctober 2013 in Mardan Palace Otel, Antalya.

Cite this article as: Çitgez S, Demirkesen 0, Mangır N, Şimşir A, Özyurt C, Çiftçi S, Özkürkçügil C, İrkilata L, Şen I, Tarcan T, Çetinel B. What are the Predictive Factors of the Cure and Complication Rates for Midurethral Slings in the Treatment of Stress Urinary Incontinence in Women: A Multicenter and Multivariate Analysis Study. J Urol Surg $2017 ; 4: 109-116$.

๑Copyright 2017 by the Association of Urological Surgery / Journal of Urological Surgery published by Galenos Publishing House. 
Öz

analizde lojistik regresyon testi kullanılarak kür ve komplikasyon oranlarını predikte eden faktörler araştırıldı.

Bulgular: Ortalama 48 ay takip süresinde subjektif kür oranı \%84 olurken komplikasyon oranı \%11,2 oldu. Univaryan ve multivaryan analizde kür oranının genç hastalarda [ $p=0,038$, göreceli olasılıklar oranı (OR): 0,97, \%95 güven aralığı (GA): 0,95-0,99] ve saf STiK olan hastalarda ( $p=0,002$, OR: 2,17, \%95 GA: 1,31-3,60) arttığı tespit edildi. Uygulanan cerrahi tipinin komplikasyon oranlarına etki eden tek prediktif faktör olduğu tespit edildi ki bu retropubik MUS'de anlamlı olarak daha yüksekti (OR: 6,28, \%95 GA: 3,51-11,22, p<0,001).

Sonuç: Kadınlarda STiK cerrahi tedavisinde MUS başarıyla uygulanabilmektedir. Yapılan çalışmada yaş ve idrar kaçırma tipinin kür oranlarına etki eden prediktif faktörler olduğu bulunurken, uygulanan cerrahi tipinin komplikasyon oranlarını etkileyen tek prediktif faktör olduğu tespit edildi.

Anahtar Kelimeler: Stres tip idrar kaçırma, orta üretra gevşek sling, transobturator, retropubik, komplikasyon

\section{Introduction}

Stress urinary incontinence (SUI) is a common condition in women, with a prevalence of 35.5\% in urology and obstetrics and gynecology outpatient clinics in Turkey (1), similar with that in the other European countries with the rate of 35\% (2).

The main goal of the surgical treatment of SUI is to restore continence with minimal morbidity. Midurethral slings (MUS) are defined and performed continuously for the treatment of female SUI. Tension-free vaginal tape (TVT), which is a minimally invasive technique, was described in 1995 by Ulmsten and Petros (3) and has been used for the treatment of SUI in women. Despite the high success rates ranging from $84 \%$ to $95 \%$ that were notified for TVT, $(4,5,6,7)$, there are concerns regarding its operative safety. Most perioperative complications of the TVT procedure have been related to penetration into the retropubic space $(8,9)$. Transobturator tape (TOT), which was described by Delorme et al. (10) in 2001, was adopted because of perioperative and postoperative complications of TVT.

The aim of this study was to evaluate the predictive factors that could affect the effectiveness and complication rates of MUS, which has been performed for the surgical treatment of SUI in 5 medical centers in Turkey since 1999.

\section{Materials and Methods}

In this study, we included a total of 594 women (outside to in transobturator in 285, inside to out transobturator in 91 , retropubic in 218) from 5 medical centers in Turkey, who were diagnosed with urodynamic SUI and underwent a MUS operation between October 1999 and August 2011 (Table 1). The study was approved by the İstanbul University Cerrahpaşa Faculty of Medicine Local Ethics Committee (approval number: 32821). Consent form was filled out by all participants.

The median age was 53.9 (27-82) years. A postoperative follow-up period of less than 6 months was the exclusion criterion in this study.

Patients presenting with stress or mixed (stress + urgency) type urinary incontinence were evaluated with medical history, physical examination, urinalysis, urine culture, 3-day bladder diary and multichannel urodynamic studies. Provocative stress test was performed in all patients and urethral mobility and pelvic organ prolapse (POP) were evaluated. The urodynamic study consisted of uroflowmetry, measurement of post-void residual urine, 1-h pad test, cystometry and measurement of valsalva leak point pressure. Most of the urodynamic investigations in this study were performed according to the standards of International Continence Society (ICS) "Good Urodynamic Practice" after it was published (11) and the ICS terminology was used for all definitions (12). The International Consultation on Incontinence Questionnaire-Short Form (ICIQSF) was used as a patient reported outcome measure after the validation of the Turkish version in 2004 (13). In total, 246 of 594 women had completed ICIQ-SF.

All patients underwent retropubic or transobturator placement of midurethral slings as previously defined $(1,6)$ either using ready to use slings or homemade meshes by experienced surgeons or residents. All patients received intravenous antibiotic at the beginning of the operation. The operations were performed under local or general anesthesia. Cystoscopy was performed in all TVT patients, however, it was done in TOT patients if there was a hematuria or any difficulties during the passage of the trocars. The catheter was removed in the evening of the operation day in TVT group and immediately after the operation in TOT group.

Two outcome measures were evaluated; subjective cure rate and complication rate. Subjective cure was defined as the statement of the women of not experiencing any loss of urine upon

Table 1. The number of patients recruited by each of the five centers

\begin{tabular}{lll}
\hline Institution & $\mathbf{n}$ & \% \\
\hline İstanbul University Cerrahpaşa Faculty of Medicine & 307 & 51.7 \\
İzmir Ege University & 91 & 15.3 \\
İstanbul Marmara University & 81 & 13.6 \\
Kocaeli University & 67 & 11.3 \\
Ankara Gazi University & 48 & 8.1 \\
Total & 594 & 100 \\
\hline
\end{tabular}


physical activity, coughing or sneezing. Any amount of leakage was considered as surgical failure. Reported complications were bleeding, bladder perforation, other organ injury, retention, voiding dysfunction, de novo urgency, urinary infection, pain, and skin complications.

\section{Statistical Analysis}

Statistical analysis was done to assign the factors that had a significant impact on the effectiveness and complication rates of MUS. Statistical analyses were done with SPSS version 15.0. Univariate analyses were done using chi-square test, Student's t-test and the Mann-Whitney U test. Multivariate analyses were done using logistic regression analysis.

\section{Results}

The median follow-up period was 48 months. Patient characteristics are shown in Table 2. Preoperative evaluation findings and operative characteristics are shown in Table 3 and Table 4, respectively. Subjective cure rate was $84 \%$ and overall complication rate was $11.2 \%$.

In univariate analysis, age, having stress incontinence (rather than mixed or urge incontinence), presence of detrussor overactivity in preoperative urodynamic investigation, use of a ready to use mesh, and concurrent POP repair were the factors that had a significant influence on the improvement of subjective cure rate (Table 5). However, number of delivery and pregnancies, comorbidity [diabetes mellitus (DM), neurologic disease], preoperative ICIQ-SF score, abdominal leak point pressure (ALPP)

Table 2. Patient characteristics

\begin{tabular}{|c|c|}
\hline Mean age (years) & $53.9( \pm 10.7)$ \\
\hline Body mass index & $28.6(20-70)$ \\
\hline \multicolumn{2}{|l|}{ Type of incontinence } \\
\hline Mixed type & $298(50.2 \%)$ \\
\hline Stress type & $282(47.5 \%)$ \\
\hline Urge type & $13(2.2 \%)$ \\
\hline Number of pregnancies & $4.2( \pm 2.4)$ \\
\hline NSD & $2.9( \pm 1.6)$ \\
\hline Sectio & $0.07( \pm 0.3)$ \\
\hline \multicolumn{2}{|l|}{ Previous pelvic surgery } \\
\hline No & 441 (74.2\%) \\
\hline Hysterectomy & $43(7.2 \%)$ \\
\hline MUS & $21(3.5 \%)$ \\
\hline POP & $21(3.5 \%)$ \\
\hline Other & $33(5.7 \%)$ \\
\hline No data & $35(5.9 \%)$ \\
\hline
\end{tabular}

and experience of surgeon did not affect the subjective outcome. In multivariate analysis, increased age was a factor that negatively affected subjective cure rate and only to have a "stress type of incontinence" proved to improve cure rate (Table 6).

Univariate analysis of factors that could affect complication rate is shown in Table 7. Complication rate in the retropubic MUS patients were significantly higher compared to that in transobturator (either "inside-out" or "outside-in") MUS patients (50/168 vs. $17 / 359$, respectively) $(p<0.001)$. The type of mesh used also seemed to affect complication rate in univariate analysis. The complication rate was higher in patients who were operated with homemade meshes compared to those operated with ready to use meshes (17/71 vs. 50/456, respectively) $(p=0.01)$. In multivariate analysis, only the type of surgery proved to affect complication rate (Table 8). Table 9 shows the complications with respect to types of MUS.

Table 3. Preoperative findings

\begin{tabular}{ll} 
Qmax in uroflowmetry & $27.1( \pm 8.3)$ \\
PVR & $10.5( \pm 23)$ \\
VLPP & $65.4( \pm 33.2)$ \\
DOA in cystometry & $11.5 \%(68 / 594)$ \\
ICIQ-SF score & $16.3( \pm 3.6)$ \\
\hline
\end{tabular}

PVR: Post-void residual, VLPP: Vesical leak point pressure, DOA: Detrussor overactivity, ICIQ-SF: International Consultation on Incontinence Questionnaire-Short Form

Table 4. Operative characteristics

\begin{tabular}{lll} 
Mean operative time (min) & 36.4 & \pm 24.1 \\
Mean hospital stay (hours) & 39.5 & \pm 22.3 \\
Type of anesthesia & & \\
General & 359 & $60.4 \%$ \\
Spinal & 199 & $33.5 \%$ \\
Local & 5 & $0.8 \%$ \\
Experience of surgeon & & \\
Experienced & 476 & $80.1 \%$ \\
Asistant & 118 & $19.9 \%$ \\
Route of MUS insertion & & \\
TOT outside in & 285 & $48.0 \%$ \\
Retropubic & 218 & $36.7 \%$ \\
TOT inside out & 91 & $15.3 \%$ \\
Source of mesh & & \\
Ready to use & 506 & $85.2 \%$ \\
Home made & 88 & $14.8 \%$ \\
Co existance POP surgery & & \\
Yes & 65 & $10.9 \%$ \\
No & 529 & $89.1 \%$ \\
\hline MUS: Midurethral sling, TOT: Transobturator tape, POP: Pelvic organ prolapse & \\
& & \\
\hline
\end{tabular}


Table 5. Univariate analysis of factors that could effect surgical outcome

\begin{tabular}{|c|c|c|c|}
\hline Variable & Cured & Not cured & $\mathbf{p}$ \\
\hline Age, mean $( \pm S D)$ & $53.7( \pm 10.5)$ & $56.2( \pm 11.3)$ & $0.04^{* *}$ \\
\hline Number of NSD, mean $( \pm S D)$ & $2.8( \pm 1.5)$ & $3.3( \pm 1.7)$ & $0.11^{* *}$ \\
\hline \multicolumn{4}{|l|}{ Comorbidity (DM, neurologic disease) } \\
\hline Yes & 32 & 8 & $0.47^{*}$ \\
\hline Mixed & 218 & 59 & \multirow[t]{3}{*}{$0.003^{*}$} \\
\hline Stress & 239 & 29 & \\
\hline Urge & 15 & 2 & \\
\hline Preoperative ICIQ-SF score, mean ( \pm SD) & $16.3( \pm 3.6)$ & $16.2( \pm 4.0)$ & $0.72^{* *}$ \\
\hline ALPP, mean $( \pm S D)$ & $64.6( \pm 35.3)$ & $63.1( \pm 29.1)$ & $0.44^{* *}$ \\
\hline \multicolumn{4}{|l|}{ Type of surgery } \\
\hline TOT outside in & 228 & 55 & \multirow[t]{3}{*}{$0.57^{*}$} \\
\hline TOT inside out & 82 & 9 & \\
\hline Retropubic & 163 & 26 & \\
\hline \multicolumn{4}{|l|}{ Type mesh used } \\
\hline Ready to use & 433 & 72 & \multirow[t]{2}{*}{$0.001^{*}$} \\
\hline Home made & 40 & 18 & \\
\hline \multicolumn{4}{|l|}{ "Chi-square } \\
\hline \multicolumn{4}{|l|}{ "Student's t-test } \\
\hline $\begin{array}{l}\text { SD: Standard deviation, NSD: Normal spontaneous } \\
\text { overactivity, ALPP: Abdominal leak point pressure, }\end{array}$ & ional Consultatio & Questionnaire-Sh & DOA: Detrusso \\
\hline
\end{tabular}

Table 6. Multivariate analysis of factors that could effect surgical outcome

\begin{tabular}{|c|c|c|c|c|c|c|}
\hline & B & SE & Wald & df & $\mathbf{p}$ & $\operatorname{Exp}(B)$ \\
\hline Age & -0.02 & 0.01 & 4.29 & 1 & 0.038 & 0.97 \\
\hline Type of incontinence, stress & 0.77 & 0.25 & 9.1 & 1 & 0.002 & 2.1 \\
\hline Type of mesh (home made vs. ready to use) & 0.62 & 0.34 & 4.34 & 1 & 0.067 & 1.87 \\
\hline Concurrent POP repair & -0.52 & 0.44 & 1.35 & 1 & 0.244 & 0.59 \\
\hline DOA in urodynamics & -0.57 & 0.33 & 2.90 & 1 & 0.088 & 0.56 \\
\hline
\end{tabular}


Table 7. Univariate analysis of factors that could effect complication rate

\begin{tabular}{|c|c|c|c|c|}
\hline Variable & Complication & No complication & $\mathbf{p}$ & Total \\
\hline Age, mean $( \pm S D)$ & $52.6( \pm 9.0)$ & $54.0( \pm 10.9)$ & $0.28^{* *}$ & \\
\hline Number of NSD, mean $( \pm S D)$ & $2.97( \pm 1.6)$ & $2.95( \pm 1.5)$ & $0.91^{* *}$ & \\
\hline \multicolumn{5}{|l|}{ Comorbidity (DM, neurologic disease) } \\
\hline Yes & 5 & 41 & $0.9^{*}$ & 46 \\
\hline Preoperative ICIQ-SF score, mean $( \pm \mathrm{SD})$ & $15.3( \pm 4.7)$ & $16.3( \pm 3.5)$ & $0.65^{* * *}$ & \\
\hline \multicolumn{5}{|l|}{ DOA in urodynamics } \\
\hline Yes & 10 & 58 & $0.34^{*}$ & 68 \\
\hline No & 57 & 468 & & 526 \\
\hline ALPP, mean $( \pm S D)$ & $59.3( \pm 30.7)$ & $65.9( \pm 34.9)$ & $0.15^{* *}$ & \\
\hline Retropubic & 50 & 168 & & 218 \\
\hline \multicolumn{5}{|l|}{ Type mesh used } \\
\hline Ready to use & 50 & 456 & $0.01^{*}$ & 506 \\
\hline Home made & 17 & 71 & & 88 \\
\hline Postoperative ICIQ-SF score, mean $( \pm$ SD) & $5.0( \pm 6.2)$ & $3.1( \pm 5.6)$ & $0.25^{* * *}$ & \\
\hline \multicolumn{5}{|l|}{ Concurrent POP repair } \\
\hline Yes & 5 & 60 & 0.33 & 65 \\
\hline No & 62 & 467 & & 529 \\
\hline
\end{tabular}

Table 8. Multivariate analysis of factors that could effect complication rates

\begin{tabular}{|c|c|c|c|c|c|c|}
\hline & B & SE & Wald & df & $\mathbf{p}$ & $\operatorname{Exp}(B)$ \\
\hline Type of surgery (Transobturator vs. retropubic ) & -0.888 & 0.182 & 23.7 & 1 & 0.000 & 0.411 \\
\hline Type of mesh (home made vs. ready to use) & -0.611 & 0.414 & 2.174 & 1 & 0.140 & 0.543 \\
\hline
\end{tabular}

B: Coefficient, SE: Standard error, df: Degree of freedom, Exp (B): Confidence interval of odds ratio

\section{Discussion}

In the present study, the age of the patients and the type of incontinence were found to be independent factors affecting the cure rates of MUS in the treatment of SUI in women. There are studies assessing the risk factors affecting cure and complication rates after MUS $(14,15,16)$. The factors that have been demonstrated to affect success following MUS procedure were the type of incontinence, previous continence surgery, age, body mass index, usage of anticholinergic medications preoperatively, concurrent prolapse surgery and the type of surgery $(14,15,16)$.

There are several studies that demonstrated the relationship between the age of the patient and success of MUS. Chen et al. (17) reported that the success rate of transobturator MUS was greater in women aged 60 years old or younger, compared with those older than 60 years [odds ratio (OR): $11.7 ; 95 \%$ confidence interval (Cl): 1.8-76]. Patient age was found the only statistically significant parameter affecting the cure rate in another study 
Table 9. The complications with respect to types of midurethral sling

\begin{tabular}{|c|c|c|c|c|c|}
\hline & \multicolumn{2}{|c|}{ Transobturator } & \multicolumn{2}{|c|}{ Retropubic } & \\
\hline & $\mathbf{n}$ & $\%$ & $\mathbf{n}$ & $\%$ & \\
\hline Overall complications & $17 / 359$ & 4.7 & $50 / 168$ & 29.7 & $0.001^{*}$ \\
\hline Immediate complications & 1 & 0.3 & 3 & 1.8 & \\
\hline - Hemorrhage & - & - & 1 & 0.6 & \\
\hline - Bladder perforation & 1 & 0.3 & 2 & 1.2 & \\
\hline Short term complications & 16 & 4.4 & 47 & 27.9 & \\
\hline - Voiding dysfunction & 8 & 2.2 & 31 & 18.4 & \\
\hline - Infections & 1 & 0.3 & 3 & 1.8 & \\
\hline - Pain & 2 & 0.5 & 8 & 4.7 & \\
\hline - Skin infection and erosion & 5 & 1.4 & 5 & 3.0 & \\
\hline
\end{tabular}

and the cure rate was significantly lower in TVT patients over 55 years of age (18). However, there are also several studies that have demonstrated satisfactory outcomes after TVT in elderly patients $(19,20)$. Nonetheless, elderly is known to be a greater risk for morbidity in any surgery. In this study, the subjective cure rate was lower in elderly patients (OR: $0.97,95 \% \mathrm{Cl}$ : $0.95-$ 0.99, $p=0.038$ ).

Mixed urinary incontinence was found to be a significant independent predictor for failure in our study. Holmgren et al. (21) reported that the long-term (8 years) cure rate after TVT in women with mixed urinary incontinence was lower than in women with pure SUI (21). However, others have found that the presence of urge symptoms did not reduce the success rates $(22,23)$. Existing literature showed the difference between the mixed and pure SUI, however, those studies mostly included patients who were treated with retropubic MUS $(21,23)$. Our study included both retropubic and transobturator groups and demonstrated that to have a pure SUI improved the success rate 2.17 times (OR: 2.17, 95\% Cl: 1.31-3.60, $p=0.002$ ) greater than mixed incontinence. Postoperative urge incontinence remains one of the most significant reasons for patient dissatisfaction and patients with mixed urinary incontinence should be informed preoperatively about the lower cure rates.

Although the type of mesh, concurrent prolapse repair and detrussor overactivity were significant in univariant analysis, they were not affecting the outcome of the surgery significantly in multivariate analysis. Some other studies indicated these variables as independent risk factors for surgical outcome $(14,15,16)$. In a recent study, it was reported that concomitant prolapse surgery decreased the likelihood of surgical failure after MUS (14), and that concurrent prolapse surgery, taking anticholinergic medications preoperatively and increased age were independent risk factors affecting successful outcome after MUS (16).

In the present study, number of delivery and pregnancies, comorbidity (DM, neurologic disease), ALPP, and preoperative ICIQ-SF score did not affect the surgical outcome. However, it was observed that women with an ALPP of $60 \mathrm{~cm} \mathrm{H}_{2} \mathrm{O}$ or less had 12 times greater risk for continued SUI than women with a ALPP of more than $60 \mathrm{~cm} \mathrm{H}_{2} \mathrm{O}$ (24). In this study, we found no relationship between ALPP and treatment outcome. Pregnancy, delivery and other conditions, such as comorbidities, have been evaluated in the literature and identified as risk factors for SUI (25), however, they were not found as independent risk factors for outcome in our study. In addition, preoperative ICIQ-SF score that revealed the degree of incontinence and quality of life of the women did not affect the surgical outcome, although 246 of 594 women had completed ICIQ-SF score sheet in this study.

The complication rate in the retropubic MUS patients was significantly higher compared to that in transobturator (either "inside out" or "outside in") MUS patients. The type of the surgery predicts the complication rate of MUS. In addition, our study demonstrated that among the predictive factors that could affect the complication rates associated with MUS. Only the type of surgery proved to affect complication rate.

The complication rates are higher with retropubic routes than with transobturator tapes (26), although there are some studies against this conclusion $(27,28,29)$. For instance, a randomized comparative trial suggested that patients in transobturator group had more complications than the retropubic group (27). However, in another study, it was demonstrated that TOT was equally effective as TVT with fewer complication, and the authors suggested that TOT would be the procedure of choice (30). In our opinion, the study design is important when comparing the complications rate between two groups. Minor complications included in the study (e.g.groin pain) and follow-up time could affect the complication rates of MUS. Similarly, Latthe et al. (31) reported that the rate of major complications, such as bladder injuries and haematomas, was higher in TVT than in TOT. However, groin/thigh pain and vaginal injuries were lower in TVT than 
in TOT (31). Additionally, operator experience may be another important factor for the complication rates. However, experience of surgeon did not affect the outcome and complication rate of the surgery in our study. Hence, most of the surgeries were performed by experienced surgeons with residents observing by experienced surgeons during the procedure in our study. In the existing literature, there are several major complications after retropubic MUS, such as nerve, bowel or major vascular injuries, pelvic hematoma, necrotizing fasciitis, ischiorectal abscess, and even death (26). Notwithstanding, the majority of complications were not reported in small randomized controlled trials. In the present study, reported complications were bleeding, bladder perforation, other organ injury, retention, voiding dysfunction, de novo urgency, urinary infection, pain, and skin complications (Table 9). The risk of complication in retropubic MUS was 6.28 (95\% Cl: $3.51-11.22, p<0.001)$ times higher than in transobturator MUS in a 48-month follow-up period.

\section{Study Limitations}

Some limitations should be pointed out with regard to our study design. The retrospective nature was the first bias of our study. Besides, this study was not a randomized trial. However, it was a multicenter study including sites throughout the country. The operations were performed by different surgeons and this point could be thought as another bias. However, the cure rate was not affected by the experience of the surgeon.

\section{Conclusion}

We conclude that age of the patient and type of incontinence were significant predictive factors affecting the cure rate for MUS in women with SUI. Risk factors for treatment failure are similar for TVT and TOT. However, retropubic approach should be considered a high risk factor for complication after MUS.

\section{Ethics}

Ethics Committee Approval: The study was approved by the İstanbul University Cerrahpaşa Faculty of Medicine Local Ethics Committee (approval number: 32821).

Informed Consent: Consent form was filled out by all participants.

Peer-review: Externally peer-reviewed.

\section{Authorship Contributions}

Surgical and Medical Practices: O.D., B.Ç., C.Özyurt, T.T., C.Ö., I.Ş., Concept: S.Ç., O.D., C.Özyurt, C.Ö., B.Ç., Design: S.Ç., O.D., T.T., B.Ç., Data Collection or Processing: S.Ç., N.M., C.Ö., S.Çiftçi, L.i.., i.Ş., Analysis or Interpretation: S.Ç., O.D., N.M., A.Ş., Literature Search: C.Özyurt, I.Ş., N.M., T.T., Writing: S.Ç., N.M., T.T., O.D.

Conflict of Interest: No conflict of interest was declared by the authors.
Financial Disclosure: The authors declared that this study received no financial support.

\section{References}

1. Cetinel B, Demirkesen O, Tarcan T, Yalcin O, Kocak T, Senocak M, Itil I. Hidden female urinary incontinence in urology and obstetrics and gynecology outpatient clinics in Turkey: what are the determinants of bothersome urinary incontinence and help-seeking behavior? Int Urogynecol J Pelvic Floor Dysfunct 2007;18:659-664.

2. Hunskaar S, Lose G, Sykes D, Voss S. The prevalence of urinary incontinence in women in four European countries. BJU Int 2004;93:324-330.

3. Ulmsten U, Petros P. Intravaginal slingplasty (IVS); an ambulatory surgical procedure for treatment of female urinary incontinence. Scand J Urol Nephrol 1995;29:75-82.

4. Ulmsten $\mathrm{U}$, Johnson $\mathrm{P}$, Rezapour M. A three-year follow up of tension free vaginal tape for surgical treatment of female stress urinary incontinence. Br J Obstet Gynaecol 1999;106:345-350.

5. Nilsson CG, Kuuva N. The tension-free vaginal tape procedure is successful in the majority of women with indications for surgical treatment of urinary stress incontinence. BJOG 2001;108:414-419.

6. Debodinance $\mathrm{P}$, Delporte P, Engrand JB, Boulogne M. Tension-free vaginal tape (TVT) in the treatment of urinary stress incontinence: 3 years experience involving 256 operations. Eur J Obstet Gynecol Reprod Biol 2002;105:49-58.

7. Meschia $M$, Pifarotti $P$, Bernasconi $F$, Guercio $E$, Maffiolini $M$, Magatti $F$, Spreafico L. Tension-Free Vaginal Tape: Analysis of outcomes and complications in 404 Stress Incontinent Women. Int Urogynecol J Pelvic Floor Dysfunct 2001;12(Suppl 2):24-27.

8. Kuuva N, Nilsson CG. A nationwide analysis of complications associated with the tension-free vaginal tape (TVT) procedure. Acta Obstet Gynecol Scand 2002;81:72-77.

9. Zilbert AW, Farrell SA. External iliac artery laceration during tension-free vaginal tape procedure. Int Urogynecol J Pelvic Flor Dysfunct 2001;12:141-143.

10. Delorme E, Droupy S, De Tayrac R, Delmas V. Transobturator tape (Uratape). A new minimally invasive treatment for female urinary incontinence. Prog Urol 2003;13:656-659.

11. Schäfer W, Abrams P, Liao L, Mattiasson A, Pesce F, Spangberg A, Sterling $A M$, Zinner NR, van Kerrebroeck P; International Continence Society. Good urodynamic practices: uroflowmetry, filling cystometry, and pressure-flow studies. Neurourol Urodyn 2002;21:261-274.

12. Abrams $P$, Cardozo $L$, Fall $M$, Griffiths $D$, Rosier $P$, Ulmsten $U$, van Kerrebroeck $P$, Victor A, Wein A; Standardisation Sub-committee of the International Continence Society. The standardisation of terminology of lower urinary tract function: report from the Standardisation Sub-committee of the International Continence Society. Neurourol Urodyn 2002;21:167-178.

13. Cetinel B, Ozkan B, Can G. The validation study of ICIQ-SF turkish version. Turk J Urol 2004;30:332-338.

14. Stav K, Dwyer PL, Rosamilia A, Schierlitz L, Lim YN, Lee J. Risk factors of treatment failure of midurethral sling procedures for women with urinary stress incontinence. Int Urogynecol J 2010;21:149-155.

15. Paick JS, Cho MC, Oh SJ, Kim SW, Ku JH. Factors influencing the outcome of mid urethral sling procedures for female urinary incontinence. J Urol 2007;178:985-989.

16. Barber MD, Kleeman $S$, Karram MM, Paraiso MF, Ellerkmann M, Vasavada $S$, Walters MD. Risk factors associated with failure 1 year after retropubic or transobturator midurethral slings. Am J Obstet Gynecol 2008;199:666.

17. Chen HY, Yeh LS, Chang WC, Ho M. Analysis of risk factors associated with surgical failure of inside-out transobturator vaginal tape for treating urodynamic stress incontinence. Int Urogynecol J Pelvic Floor Dysfunct 2007; 18:443-447. 
18. Cetinel B, Demirkesen O, Onal B, Akkus E, Alan C, Can G. Are there any factors predicting the cure and complication rates of tension-free vaginal tape? Int Urogynecol J Pelvic Floor Dysfunct 2004;15:188-193.

19. Nager CW, FitzGerald M, Kraus SR, Chai TC, Zyczynski H, Sirls L, Lemack GE, Lloyd LK, Litman HJ, Stoddard AM, Baker J, Steers W; Urinary Incontinence Treatment Network. Urodynamic measures do not predict stress continence outcomes after surgery for stress urinary incontinence in selected women. J Urol 2008;179:1470-1474.

20. Sevestre S, Ciofu C, Deval B, Traxer O, Amarenco G, Haab F. Results of the tension-free vaginal tape technique in the elderly. Eur Urol 2003;44:128131.

21. Holmgren C, Nilsson S, Lanner L, Hellberg D. Long-term results with tensionfree vaginal tape on mixed and stress urinary incontinence. Obstet Gynecol 2005;106:38-43.

22. Kulseng-Hanssen $\mathrm{S}$, Husby $\mathrm{H}$, Schiøtz HA. Follow-up of TVT operations in 1,113 women with mixed urinary incontinence at 7 and 38 months. Int Urogynecol J Pelvic Floor Dysfunct 2008;19:391-396.

23. Lee JH, Cho MC, Oh SJ, Kim SW, Paick JS. Long-term outcome of the tension-free vaginal tape procedure in female urinary incontinence: a 6-year follow-up. Korean J Urol 2010;51:409-415.

24. O'Connor RC, Nanigian DK, Lyon MB, Ellison LM, Bales GT, Stone AR. Early outcomes of mid-urethral slings for female stress urinary incontinence stratified by valsalva leak point pressure. Neurourol Urodyn 2006;25:685-688.

25. Luber KM. The definition, prevalence, and risk factors for stress urinary incontinence. Rev Urol 2004;6(Suppl 3):3-9.
26. Ogah J, Cody DJ, Rogerson L. Minimally invasive synthetic suburethral sling operations for stress urinary incontinence in women: a short version Cochrane review. Neurourol Urodyn 2011;30:284-291.

27. Laurikainen E, Valpas A, Kivelä A, Kalliola T, Rinne K, Takala T, Nilsson CG. Retropubic compared with transobturator tape placement in treatment of urinary incontinence: a randomized controlled trial. Obstet Gynecol 2007;109:4-11.

28. Ross S, Robert M, Swaby C, Dederer L, Lier D, Tang S, Brasher P, Birch C, Cenaiko D, Mainprize $T$, Murphy $M$, Carlson $K$, Baverstock $R$, Jacobs $P_{1}$ Williamson T. Transobturator tape compared with tension-free vaginal tape for stress incontinence: a randomized controlled trial. Obstet Gynecol 2009;114:1287-1294.

29. Schierlitz L, Dwyer PL, Rosamilia A, Murray C, Thomas E, De Souza A, Lim YN, Hiscock R. Effectiveness of tension-free vaginal tape compared with transobturator tape in women with stress urinary incontinence and intrinsic sphincter deficiency: a randomized controlled trial. Obstet Gynecol 2008;112:1253-1261.

30. deTayrac R, Deffieux $X$, Droupy $S$, Chauveaud-Lambling $A$, CalvanèseBenamour L, Fernandez H. A prospective randomized trial comparing tension-free vaginal tape and transobturator suburethral tape for surgical treatment of stress urinary incontinence. Am J Obstet Gynecol 2004;190:602-608.

31. Latthe PM, Singh P, Foon R, Toozs-Hobson P. Two routes of transobturator tape procedures in stress urinary incontinence: a meta-analysis with direct and indirect comparison of randomized trials. BJU Int 2010;106:68-76. 